Journal of Educational Technology

\& Online Learning

Volume 5 | Issue 1 2022

http://dergipark.org.tr/jetol

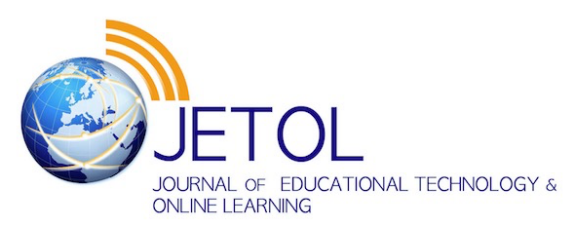

\title{
Technology integration in teaching English as a foreign language: A content analysis study
}

\author{
Tarık Başar ${ }^{a *}$ (D), Leyla Şahin ${ }^{b}(\mathbb{D}$ \\ ${ }^{a}$ Kırşehir Ahi Evran University, Turkey \\ ${ }^{\mathrm{b}}$ Ministry of National Education, Turkey
}

Suggested citation: Başar, T. \& Şahin, L. (2022). Technology integration in teaching English as a foreign language: A content analysis study. Journal of Educational Technology \& Online Learning, 5(1), 204-222.

\begin{tabular}{ll}
\hline Article Info & \begin{tabular}{l} 
Abstract \\
\cline { 2 - 2 } $\begin{array}{l}\text { Keywords: } \\
\text { Teaching English as a foreign } \\
\text { language }\end{array}$
\end{tabular} $\begin{array}{l}\text { The main purpose of this research is to identify research trends that have been conducted } \\
\text { over the last five years }(2016-2020) \text { on the role of technology integration in teaching } \\
\text { English as a foreign language. For this purpose, the descriptive content analysis is used } \\
\text { in the research. In accordance with the keywords, systematic review was carried out and }\end{array}$ \\
$\begin{array}{l}\text { Foreign language/second } \\
\text { language teaching }\end{array}$ & $\begin{array}{l}366 \text { studies were included in the scope of the research. The study has revealed that there } \\
\text { is an increasing trend in the number of studies from } 2016 \text { onwards and what's more, } \\
\text { flipped learning and mobile-assisted language learning subjects are among the mostly } \\
\text { studied subjects. In the studies, experimental designs were chosen more, as a data } \\
\text { collection tool, questionnaire/scale was preferred; and descriptive statistics were } \\
\text { preferred more as a data analysis technique. In most of the studies, the sample group } \\
\text { consists of university students and the sample size is in the range of } 0-50 . \text { In addition, } \\
\text { when the results in the studies within the scope of the research are analyzed, the most } \\
\text { obtained result is that the participants views on technology integration are positive. } \\
\text { Based on the trends of the studies examined within the scope of the research, this study } \\
\text { offers recommendations for the future studies in the field. }\end{array}$ \\
Research Article &
\end{tabular}

\section{Introduction}

In the 21 st century we have lived in, it is possible to see technology integration in all areas of life. Technology has been integrated into human life (Solak \& Erdem, 2015) via computers, mobile devices, social media platforms, etc. Technology integration brings many innovations and changes in social, cultural, economic areas. Thus, it can be said that "changing" is the only reality that does not change in the 21 st century when technology integration is incorporated into all areas of life (Polat Demir \& Kutlu, 2016). Education is one of the most important areas where this changing occurs due to the technology integration. Prensky (2001), identifying today's students as digital natives, states that the new generation grows up with technology from an early age, therefore; students are natural speakers of this technological language. Accordingly, the integration of technology in education is a real need for the students who grow up with the technology of the 21 st century (Chapelle, 2003). For this reason, in today's conditions, the use of technological tools in the teaching-learning process has become a necessity, not a choice, in order to provide students with better learning opportunities (Aduwa-Ogiegbaen, 2009; Okojie, Olinzock, Okojie-Boulder, 2006).

\footnotetext{
* Corresponding author. Department of Education Sciences, Kırşehir Ahi Evran University, Turkey.

e-mail address: tarik.basar@ahievran.edu.tr
} 
Foreign language education has also been affected by the changes in education with technology integration (Arslan \& Akbarov, 2010; Pokrivcakova, 2019). Foreign language education has a crucial importance today in particular. The developments in information and communication technologies have removed barriers among countries, and on this occasion information sharing and communication have come into the prominence (Aslan, 2017). For this reason, foreign language learning has become a vital need for individuals in the globalizing world (Özer \& Korkmaz, 2016; Türkben, 2018; Türker \& Genç, 2018). English, widely used all over the world -among all foreign languages- as lingua franca, is in the forefront (Demir \& Yavuz, 2014). English, accepted as a common language, is mostly spoken language all over the world (Suna \& Durmuşçelebi, 2013). Technology integration must be adopted so as to teach English language in an effective way, which is crucial in today's world. In other words, foreign language teaching should not be based on traditional methods in which learners are passive recipients of information (Valeev, Latypova \& Latypov, 2016). Teaching foreign language with traditional teaching methods to the digital natives is too tough (Türker \& Genç, 2018). Traditional English teaching methods prevent to make learning environments suitable for students' individual needs and learning styles. Traditional teaching methods can also cause learners to get bored and lose their motivation in the language learning process (Hazarika, 2017). Additionally, it is very difficult to reach the main goal of communication by means of traditional teaching methods. Traditional teaching methods make understanding the structure, meaning and applying function of a language difficult for learners (Shyamlee \& Phil, 2012).

Interactive learning environments are improved with technology integration in foreign language teaching, thus learners can use the foreign language that they have learned (Aslan, 2017). In other words, the language learning process turns into learner centered. Moreover, learners' motivation for learning foreign languages increases (Ahmadi, 2018). Therefore, technology integration makes it easier to learn a foreign language (Aydın, 2018). Technology integration, facilitating the learning of the English language, could be achieved with various technological tools. Online English learning websites, electronic dictionaries, computer assisted language learning programs, various chat programs, virtual conferences and mobile assisted language learning can be given as an example (Hazarika, 2017).

\subsection{The Importance of Study}

With the integration of technology into foreign language teaching, studies examining this situation have started to be carried out in the literature. In other words, studies examining the effectiveness and the role of technology integration in foreign language teaching have been carried out. Especially in the 2000s, when computer and internet usage became widespread, these studies started to take place in the literature (Zengin $\&$ Aksu, 2017). In these studies, various types of technology integration were examined in terms of foreign language teaching. Most of these studies were focused on teaching English as a foreign language. For example; flipped learning (Kırmızı \& Kömeç, 2019; Suranakkharin, 2017; Teng, 2017), computer assisted learning (Alhujaylan, 2019; Enayati \& Gilakjani, 2020; Kızmaz, 2019) mobile learning (Almogheerah, 2020; Bensalem, 2018; Şahan, Çoban \& Razı, 2016), multimedia (Kaymak, 2019; Mei, Guo \& Li, 2017; Zhao et al., 2019), augmented reality (Akçayır \& Akçayır, 2016; Ho, Hsieh, Sun \& Chen, 2017; Tsai, 2020) and such studies were conducted on the role of teaching English as a foreign language. There are many studies on the role of technology integration in teaching English as a foreign language in the literature. Content analysis study that summarizes and presents a synthesis of these studies is needed. In other words, there is a need for content analysis study that reveals the trends of the studies in the literature.

In the literature, there are lots of content analysis studies on the role of technology integration in foreign language teaching. However, these studies generally focus on a single type of technology integration. For instance, the role of flipped learning (Arslan, 2020; Filiz \& Benzet, 2018), mobile learning (Persson \& Nouri, 2018; Uzunboylu \& Genç, 2017; Viberg \& Grönlund, 2012), virtual reality (Solak \& Erdem, 2015) related studies, which is in foreign language teaching are included in the literature. However, there is no restriction in the present study and all studies involving technology integration have been included. Thus, 
both the general trend in the literature has been determined and the types of technology integration used in the studies have also been revealed.

There are also meta-analysis studies presenting a synthesis of the studies on the role of technology integration in foreign language teaching in the literature (Al-Wasy, 2020; Chang \& Hung, 2019; Haidari, Baysal \& Kanadlı, 2020; Köprülü, Öznacar \& İlginç Demirsu, 2020). But only experimental studies were based on these meta-analysis studies. However, no method restrictions were made in this study and thus, the methodological trends in the literature has also been revealed.

In addition, another factor that makes this research valuable for the literature is the presentation of a synthesis of the results and suggestions from the studies. It is believed that the trends put forward the results and suggestions of the studies conducted in the literature will also be a guide for the future studies. Another factor that makes this research different from the other content analysis studies in the literature is the determination of trends in both national and international areas. In other words, the similarities and differences were brought out in this study by comparing the field trends not only in Turkey but also in international field.

The results obtained from this research will not only give the trends in the literature, but also provide clues for the deficiencies. It is thought that these clues will be a guide for future studies. In other words, it is thought that findings will lead different studies instead of similar studies in the literature. In addition, it is thought that this study will be a guide for teachers and researchers who want to benefit from technology integration in teaching English as a foreign language.

\subsection{The Purpose of Study}

The main purpose of the research is to present a synthesis of the studies conducted in the last five years on the role of technology in teaching English as a foreign language in both national and international literature. In other words, this study aims to identify research trends on this subject in the literature.

The following research questions guide this study:

- What is the distribution of the studies in terms of years of publication?

- What is the distribution of the studies in terms of subjects?

- What is the distribution of the studies in terms of research designs?

- What is the distribution of the studies in terms of data collection tools?

- What is the distribution of the studies in terms of data analysis techniques?

- What is the distribution of the studies in terms of sample groups?

- What is the distribution of the studies in terms of sample sizes?

- What is the distribution of the studies in terms of results?

- What is the distribution of the studies in terms of suggestions?

\section{Methodology}

This research is qualitative research and is designed as based on the descriptive content analysis, one of the content analysis approaches. In the descriptive content analysis approach, research trends on a specific subject are revealed (Çalık \& Sözbilir, 2014). As it is aimed to identify research trends conducted over the last five years (2016-2020) on the role of technology integration in teaching English as a foreign language, descriptive content analysis approached is used in this study. 


\subsection{Data Collection}

Firstly, it was decided which databases would be accessed for the studies so as to include in the scope of the research during the data collection process. In this sense, two national and one international databases were selected. National databases consist of Council of Higher Education National Thesis Center and TR Index database. Council of Higher Education National Thesis Center was preferred as it contains all postgraduate thesis studies in Turkey. TR Index database was preferred since it is a database where many journals were scanned in Turkey. In addition, TR Index was used as a database in which it is compulsory to publish an article in applications for associating professorship in Educational Sciences field in Turkey. WOS [WEB of Science] database was chosen as an international level. According to Cok (2016), WOS is a reliable database that scans the most important scientific journals in the field of education, information, and communication technology. For this reason, international studies were tried to be reached through the WOS database.

In the research, after deciding on the databases, the keywords that will be scanned in these databases were tried to be determined. In this context, an expert in the field of instructional technologies and an expert in the field of second language teaching were consulted. According to opinions, a comprehensive list of keywords has been developed. That many keywords have been identified as technology is a multidimensional concept. Therefore, a scan was carried out by using a large number of keywords in the databases. Consequently, it has been tried to include all studies related to the subject in the literature. The following keywords were used in the scan: "technology", "technology integration", "instructional technologies", "flipped learning", "web 2.0 technologies", "computer assisted learning", "mobile learning", "virtual classroom", " "digital games", "digital learning", "multimedia", "augmented reality", "social networks", "distance learning", "blended learning", web-based learning", "online learning", "simulation", "animation" ", "technology assisted language teaching" and "English as a foreign language".

In the research, all three databases were reviewed in terms of identified keywords. Studies included in the scope of the research were decided in the light of the criteria stated below.

These criteria are:

- The study has been published in the last five years (2016-2020).

- The subject of the study is about technology integration in foreign language teaching.

- The foreign language studied in the study is English.

- The full text of the study is accessible.

In the research, studies fulfilling the above criteria were included in the scope of the research. Also, articles produced from postgraduate thesis studies at the national level were excluded from the research in order not to repeat the same data.

Numerical information about the studies included in the scope of the research is presented in Table 1:

Table 1.

Numerical Information About the Studies

\begin{tabular}{lllll}
\hline & & National (f) & International (f) & Total (f) \\
\hline \multirow{3}{*}{ Publication Type } & Master's Thesis & 87 & - & 87 \\
& Doctoral Thesis & 19 & - & 19 \\
& Article & 40 & 220 & 260 \\
\multirow{2}{*}{ Publication Language } & Turkish & 44 & - & 44 \\
& English & 102 & 220 & 322 \\
\hline Total & & 146 & 220 & 366 \\
\hline
\end{tabular}


On study of Table 1, it is seen that total of 366 studies, 146 at the national level and 220 at the international level, were included in the research. When the studies examined within the scope of the research are analyzed in terms of publication language, it is seen that the publication language is English in most of the studies conducted at the national level (f: 102).

A form called "publication review form" was developed to examine the studies included in the research. This form consists of 12 sections. The first 5 sections of the form constitute the sections in which information about the author of the study, publication type, publication year, publication language and national/international nature of the publication are specified. In other words, the first five sections are the sections in which descriptive information is given about identity of the study. The 6th, 7th, 8th, 9th and 10th sections are the sections in which information about the research design, data collection tools, data analysis techniques, sample group and sample size are stated respectively. In other words, these five sections are the sections in which the methodological features of the studies examined are stated. The last two sections of the form are the sections in which information about the results from the studies and the suggestions are stated.

\subsection{Data Analysis}

Content analysis technique was used in the analysis of the collected data in the research. Content analysis is the process of organizing the data from the research into categories (Bowen, 2009). According to Merriam (2009), categorization is a data analysis, which should be carried out together with the data collection process. In this sense, data analysis was started with the data collection process in the research. While the studies included in the scope of the research were examined according to the sections contained in the publication review form, the process of creating a category for the sections in the form was started. In this context, at first researchers examined $10 \%$ of the studies included in the scope of the research simultaneously. During this review process, researchers developed categories for sections in which the methodological characteristics of the studies and their results and suggestions were stated in the publication review form. For example, primary school student, middle school student, high school student, university student, teacher, instructor categories were developed for the sample group. Then, researchers analyzed the studies independently from each other within the framework of the determined categories. During this independent review process, new different categories emerged for each section. Researchers came together for these new different categories and discussed these categories and revised the form according to the new categories. For example, new categories such as pre-service teacher, language school student were added to the form for the sample group. Accordingly, the category improvement process continued until the data analysis was completed.

The studies examined within the scope of the research were classified according to one or more categories for each section of the publication review form. For example, data collection tool section of the form was classified in 3 different categories in some studies: interview, questionnaire, and achievement test. In the study, frequency values were calculated for each classified category.

In the study, the percentage of compliance between the researchers was calculated by comparing the categories that both researchers classified independently from each other. This percentage of agreement was calculated using the formula proposed by Miles and Huberman (1994) (agreement/agreement + disagreement) and this value was determined as .96. This value also shows that the categories classified within the scope of the research are reliable. 


\section{Findings}

\subsection{Findings of Publication Years of the Studies}

The distribution of the studies in terms of years between 2016 and 2020 is presented in Graphic 1.

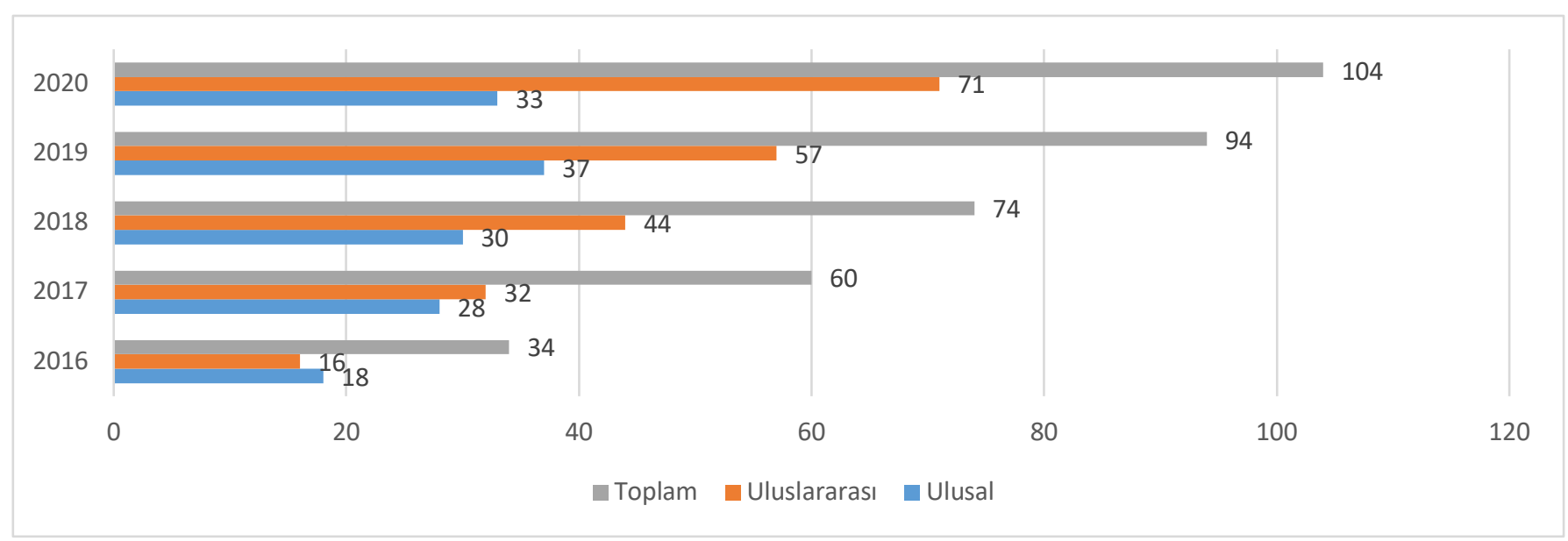

Graphic 1. Distribution of the Studies in terms of Publication Year

As indicated graphic 1, the studies were carried out in 2020 at most. In addition, there is an increasing trend in the number of studies from 2016 onwards.

\subsection{Findings of Subjects of the Studies}

The distribution of the studies in terms of subjects is presented in Table 2:

\section{Table 2.}

Distribution of the Studies in terms of Subjects

\begin{tabular}{llll}
\hline Subject of the study & National (f) & International(f) & Total (f) \\
\hline The role of flipped learning & 33 & 32 & 65 \\
\hline The role of mobile assisted language learning & 12 & 33 & 45 \\
\hline The role of computer-assisted language learning & 16 & 19 & 35 \\
\hline The role of blended learning & 16 & 13 & 29 \\
\hline The role of digital games & 2 & 17 & 19 \\
\hline The role of social networks & 5 & 16 & 21 \\
\hline The role of multimedia & 3 & 17 & 20 \\
\hline The role of Web 2.0 tools & 12 & 7 & 19 \\
\hline The role of online learning & 3 & 13 & 15 \\
\hline The role of augmented reality & 6 & 9 & 13 \\
\hline The role of distance education & 8 & 5 & 11 \\
\hline Availability of technology & 6 & 5 & 10 \\
\hline Technological pedagogical content knowledge & 4 & 6 & 48 \\
\hline Other & 20 & 28 & \\
\hline
\end{tabular}

As shown in the table 2, the most studied subject in the studies is the role of flipped learning (f:65) in teaching English as a foreign language. The role of mobile-assisted language learning (f:45) and the role of computer-assisted language learning (f:35) are another most studied subjects. Study subjects with low frequency (web-based learning, digital story, digital literacy, etc.) are given under the title of "other" section in the table.

\subsection{Findings of Research Designs of the Studies}

The distribution of the studies in terms of research designs is presented in Table 3: 
Table 3.

Distribution of the Studies in terms of Research Designs

\begin{tabular}{llll}
\hline Research design & National (f) & International (f) & Total (f) \\
\hline Experimental Design & 41 & 81 & 122 \\
\hline Descriptive/ Survey Model & 28 & 39 & 67 \\
\hline Case study & 20 & 16 & 36 \\
\hline Review & 5 & 20 & 25 \\
\hline Mixed Design (explanatory sequential design) & 11 & 10 & 21 \\
\hline Action research & 5 & 11 & 15 \\
\hline Mixed Design (unspecified type) & 9 & 6 & 9 \\
\hline Embedded design & 5 & 4 & 7 \\
\hline Meta-analysis & 2 & 5 & 4 \\
\hline Phenomenology & 2 & 2 & 3 \\
\hline Mixed Design (Triangulation) & 2 & 1 & 2 \\
\hline Mixed Design (exploratory sequential design) & 1 & 1 & 2 \\
\hline Mixed Design (convergent parallel design & - & 2 & 2 \\
\hline Mixed Design (Intervention Design) & 2 & - & 13 \\
\hline Other & 6 & 7 & 22 \\
\hline Unspecified & 7 & 15 & \\
\hline
\end{tabular}

As seen in Table 3, the most preferred research design is the experimental design (f:122). After the experimental design, the most preferred designs are the descriptive/survey model (f:67) and the case study model (f:36). In addition, it is seen that the explanatory sequential design (f:21) is mostly used design type among the mixed design types in research. However, in many studies where mixed design was preferred (f:15), the design type was not specified. Additionally, in some of the studies (f:22), the research design was not clearly stated. In the table, research designs with low frequency (comparative study, corpus design, discourse analysis and so on) are presented under the title of "other" section.

\subsection{Findings of Data Collection Tools of the Studies}

The distribution of the studies in terms of data collection tools is presented in Table 4:

Table 4.

Distribution of the Studies in terms of Data Collection Tools

\begin{tabular}{llll}
\hline Data collection tool & National(f) & International (f) & Total (f) \\
\hline Questionnaire /Scale & 109 & 131 & 240 \\
\hline Interview & 83 & 66 & 149 \\
\hline Achievement test & 56 & 92 & 148 \\
\hline Observation & 10 & 26 & 36 \\
\hline Reflective Diaries & 22 & 13 & 35 \\
\hline Environment/Media Records & 6 & 13 & 19 \\
\hline Course Evaluation Form & 6 & 5 & 11 \\
\hline Other & 16 & 22 & 38 \\
\hline
\end{tabular}

When Table 4 is examined, it is seen that the most frequently used data collection tool in the studies is questionnaire /scale (f:240). Interview (f:149) and achievement test (f:148) are the other most used data collection tools. Data collection tools with low frequency (student portfolios, worksheets, lesson plans, and such) are given under the title of "other" section in the table.

\subsection{Findings of Data Analysis Techniques of the Studies}

The distribution of the studies in terms of data analysis techniques is presented in Table 5: 


\section{Table 5.}

Distribution of the Studies in terms of Data Analysis Techniques

\begin{tabular}{llll}
\hline Data analysis technique & National (f) & International (f) & Total (f) \\
\hline Descriptive Statics & 69 & 124 & 193 \\
\hline $\mathrm{t}$ test & 73 & 74 & 147 \\
\hline Content analysis & 70 & 59 & 129 \\
\hline Analysis of variance & 25 & 29 & 54 \\
\hline Correlation analysis & 18 & 20 & 38 \\
\hline Descriptive analysis & 27 & 6 & 33 \\
\hline Thematic analysis & 9 & 15 & 24 \\
\hline Mann Whitney U test & 12 & 10 & 22 \\
\hline Kolmogorov-Smirnov test & 16 & 5 & 21 \\
\hline Factor analysis & 10 & 9 & 19 \\
\hline Wilcoxon signed ranks test & 14 & 2 & 16 \\
\hline Ancova analysis & 7 & 8 & 15 \\
\hline Shapiro-Wilks test & 10 & 2 & 12 \\
\hline Other & 10 & 15 & 25 \\
\hline
\end{tabular}

On examination of Table 5, it is clearly seen that the most frequently used data analysis technique in the studies is descriptive statistics (f: 193). On the other hand, t test (f:147) and content analysis (f:129) are the other most used data analysis techniques. In the table, data analysis techniques with low frequency (manova, regression, friedman test, etc.) are given under the title of "other" section.

\subsection{Findings of Sample Groups of the Studies}

The distribution of the studies in terms of sample groups is presented in Table 6:

Table 6.

Distribution of the Studies in terms of Sample Groups

\begin{tabular}{llll}
\hline Sample Group & National (f) & International (f) & Total (f) \\
\hline University student & 67 & 104 & 171 \\
\hline High school student & 18 & 15 & 33 \\
\hline Teacher & 16 & 16 & 32 \\
\hline Pre-service teacher & 15 & 15 & 30 \\
\hline Middle school student & 13 & 15 & 28 \\
\hline Instructor & 16 & 10 & 26 \\
\hline Language school students & 2 & 11 & 13 \\
\hline Primary school student & 3 & 7 & 10 \\
\hline Other & 3 & 5 & 8 \\
\hline
\end{tabular}

On examination of Table 6, it is seen that the most studied sample group is university students (f: 171). High school students (f:33) and teachers (f:32) are the other most studied sample groups. In the table, sample groups with low frequency (parents, school administrators, graduates, etc.) are given under the title of "other" section.

\subsection{Findings of Sample Sizes of the Studies}

The distribution of the studies in terms of sample sizes is presented in Table 7: 
Table 7.

Distribution of the Studies in terms of Sample Sizes

\begin{tabular}{llll}
\hline Sample size & National (f) & International (f) & Total (f) \\
\hline Between 0-50 & 71 & 86 & 157 \\
\hline Between 51-100 & 35 & 61 & 96 \\
\hline Between 101-150 & 20 & 26 & 24 \\
\hline 301 and above & 15 & 9 & 13 \\
\hline Between 151-200 & 6 & 7 & 8 \\
\hline Between 251-300 & 3 & 5 & 7 \\
\hline Between 201-250 & 3 & 4 & 56 \\
\hline
\end{tabular}

As shown in the table 7, the most studied sample size is in the range of 0-50 (f: 157). 51-100 (f:96) and 101-150 (f:46) ranges are the other most studied sample size ranges.

\subsection{Findings of Results of the Studies}

Distribution of the studies in terms of results is presented in Table 8:

\section{Table 8.}

Distribution of the Studies in terms of Results

\begin{tabular}{|c|c|c|c|}
\hline Results & National (f) & International (f) & Total (f) \\
\hline Participants' opinions on technology integration are positive. & 50 & 84 & 134 \\
\hline Technology integration increases motivation & 41 & 63 & 104 \\
\hline Technology integration affects success positively & 27 & 38 & 65 \\
\hline $\begin{array}{l}\text { Technology integration contributes to the development of self- } \\
\text { confidence and self- efficacy }\end{array}$ & 21 & 25 & 46 \\
\hline Technology integration affects course participation positively & 20 & 25 & 45 \\
\hline Technology integration supports learner autonomy & 17 & 23 & 40 \\
\hline Technology integration affects vocabulary learning positively & 19 & 20 & 39 \\
\hline Technology integration affects speaking skills positively & 12 & 27 & 39 \\
\hline Technology integration affects writing skills positively & 14 & 19 & 33 \\
\hline Technology integration enables collaboration & 11 & 21 & 32 \\
\hline Training for technology integration is needed & 18 & 14 & 32 \\
\hline Technology integration affects listening skills positively & 13 & 16 & 29 \\
\hline Technology integration affects reading skills positively & 12 & 14 & 26 \\
\hline
\end{tabular}




\begin{tabular}{llll}
\hline $\begin{array}{l}\text { Technology integration needs to be done correctly in } \\
\text { classrooms }\end{array}$ & 12 & 14 & 26 \\
\hline Technology integration is crucial for English teachers & 8 & 14 & 25 \\
\hline Technology integration makes lessons more fun & 7 & 10 & 17 \\
\hline $\begin{array}{l}\text { Technology integration improves communication skills } \\
\text { Technology integration in the teaching-learning process cannot } \\
\text { achieved adequately. }\end{array}$ & 8 & 9 & 17 \\
\hline $\begin{array}{l}\text { Technology integration reduces anxiety for foreign language } \\
\text { Technology integration affects grammar learning positively }\end{array}$ & 9 & 9 & 15 \\
\hline Other & 53 & 6 & 15 \\
\hline
\end{tabular}

As shown in the table 8, the most emphasized result in the studies is that the participants' views on the integration of technology in teaching English as a foreign language are positive (f:134). The other most emphasized result in the studies is that technology integration increases motivation ( $\mathrm{f}: 104)$ and affects success positively (f:65). In the study, the results with low frequency numbers were collected under the title of "other" section. These results include "Technology integration improves critical thinking skills"; "Technology integration contributes to the formation of permanent learning"; and "Teachers stick to a single technological tool" can be given as an example.

\subsection{Findings of Suggestions of the Studies}

The distribution of suggestions of the studies is presented in Table 9:

Table 9.

Distribution of the Studies in terms of Suggestions

\begin{tabular}{llll}
\hline Suggestions & National (f) & International (f) & Total (f) \\
\hline Different sample groups can be studied & 86 & 79 & 165 \\
\hline $\begin{array}{l}\text { Larger sample groups can be studied } \\
\text { Further research can be applied on the technological tool or }\end{array}$ & 29 & 55 & 84 \\
program used in the study & 54 & 76 \\
\hline $\begin{array}{l}\text { Technology integration can be used in different activities in the } \\
\text { teaching-learning process }\end{array}$ & 22 & 27 & 71 \\
\hline $\begin{array}{l}\text { Participants can be encouraged about technology integration by } \\
\text { organizing in-service training, seminars, etc. }\end{array}$ & 44 & 31 \\
\hline $\begin{array}{l}\text { Technology integration can be included in curricula and } \\
\text { textbooks }\end{array}$ & 36 & 23 & 67 \\
\hline $\begin{array}{l}\text { Implementation time of the study can be increased } \\
\text { Experimental studies can be designed }\end{array}$ & 37 & 21 & 60 \\
\hline $\begin{array}{l}\text { Technique and infrastructure and so on required for technology } \\
\text { integration. support can be provided }\end{array}$ & 20 & 27 & 48 \\
\hline
\end{tabular}




\begin{tabular}{llll}
\hline $\begin{array}{l}\text { Teachers can arrange on materials enabling technology } \\
\text { integration, taking into account the level and interest of students }\end{array}$ & 18 & 29 & 47 \\
\hline $\begin{array}{l}\text { Studies on different language skills can be applied } \\
\text { Studies using qualitative data collection methods can be carried } \\
\text { out }\end{array}$ & 24 & 16 & 42 \\
\hline $\begin{array}{l}\text { Studies can be applied on different technological materials that } \\
\text { allow technology integration. }\end{array}$ & 12 & 15 & 27 \\
\hline $\begin{array}{l}\text { Studies on different variables (age, socioeconomic status, school } \\
\text { type, and such) can be applied }\end{array}$ & 15 & 11 & 26 \\
\hline $\begin{array}{l}\text { Informatics courses included in teacher training programs can be } \\
\text { revised }\end{array}$ & 15 & 11 & 15 \\
\hline $\begin{array}{l}\text { Retention tests can be used } \\
\text { Foreign language lesson hours can be arranged }\end{array}$ & 7 & 7 & 13 \\
\hline $\begin{array}{l}\text { Participants can be supported to produce digital content and } \\
\text { events themselves }\end{array}$ & 8 & 6 & 12 \\
\hline $\begin{array}{l}\text { Opportunity to use authentic materials by integrating technology } \\
\text { in learning environments can be improved }\end{array}$ & 2 & 4 & 12 \\
\hline $\begin{array}{l}\text { Studies examining the effectiveness of technology integration on } \\
\text { different courses can be applied }\end{array}$ & 3 & 10 & 12 \\
\hline $\begin{array}{l}\text { Studies using quantitative data collection methods can be applied } \\
\text { Longitudinal studies can be applied }\end{array}$ & 2 & 6 & 10 \\
\hline \begin{tabular}{l} 
Other \\
\hline
\end{tabular} & 60 & 10 \\
\hline
\end{tabular}

As shown in the table 9, the most emphasized suggestion in the studies is to conduct studies in different sample groups (f:165). Conducting studies with larger sample groups (f: 116) and conducting more research on the technological tool or program used in the study (f: 84 ) are the other most emphasized suggestions in the studies. In the table, the suggestions with low frequency were presented under the title of "other" section. "Studies can be conducted to examine the reasons for the negative perception to the technology integration"; "The difficulties and negative characteristics of the technological material which was used in the study can be examined in terms of language teaching"; and "Activities can be carried out to give importance to digital literacy" can be given as examples of these suggestions.

\section{Discussion}

In this study, research trends which have been conducted over the past five years on the role of technology integration in teaching English as a foreign language are identified. In line with the obtained data, it has been concluded that there is an increasing trend in the number of studies conducted from 2016 onwards. In today's rapidly developing technology, this result can be considered as natural or ordinary. Besides, this result can be interpreted as technology integration in teaching English as a foreign language is getting more important year by year. A similar finding was obtained in the content analysis study conducted by Nawaila, Kanbul, and Alhamroni (2020). Nawaila, et al. (2020) analyzed 50 studies on the role of technology integration in English language teaching between 2000-2018 and concluded that technology integration in English language teaching has increased in the last three years. A similar finding was also obtained in the meta-analysis study conducted by Karabulut (2020) in order to determine the general impact of alternative technology-supported teaching methods on English success. In his meta-analysis study, which included 
experimental studies conducted between 1994 and 2018, Karabulut (2020) demonstrated that the number of studies has increased significantly, especially in the last three years.

When the studies within the scope of the research are analyzed in terms of the study subjects, it is concluded that there are more studies examining the role of flipped learning at the national level. At the international level, studies examining the role of flipped learning and mobile-assisted language learning were preferred mostly. When the studies in the literature are considered together, it can be seen that technology is integrated into English teaching through flipped learning and mobile language learning. These results show that especially flipped learning has become a popular approach in teaching English. According to Vitta and AlHoorie (2020), flipped learning, which is widely used in various fields of education, has also been widely used in the field of second language teaching in recent years. Mobile-assisted language learning, another popular approach in teaching English, can be considered as a reflection of mobile devices integrated into all areas of our lives. One of the most important contributions of mobile assisted language learning to foreign language teaching is that it provides the opportunity to learn the language regardless of time and place (Persson \& Nouri, 2018; Taj, Sulan, Sipra \& Ahmad, 2016). This could be one of the reasons why mobile-assisted language learning is preferred more in foreign language teaching.

When the methodological tendencies of the studies within the scope of the research are analyzed, it is concluded that the experimental design was preferred more at both national and international levels. This result can be interpreted as the investigation of the effectiveness of a technological tool or approaches in the studies were examined mostly. In other words, the role of technology integration has been tried to be determined by the direct application of technology in foreign language teaching in the studies. According to Zhao (2003), the effectiveness of technology in language teaching can only be determined by the direct application of technology. The research design that allows the direct application of technology is experimental design. Therefore, the reason why the experimental design is preferred more in the studies could arise from this situation. This finding is also consistent with study conducted by Viberg and Grönlund (2012). Viberg and Grönlund (2012) examined 54 studies conducted between 2007 and 2012 to determine the role of mobile assisted language learning in second language teaching. In this study conducted by Viberg and Grönlund (2012), it was determined that the most preferred design is the experimental design. And also, in a similar study by Persson and Nouri (2018), 54 empirical studies conducted between 2010 and 2017 were examined to determine the role of mobile assisted language learning in second language teaching. Persson and Nouri (2018) concluded in their study that the most widely used design is the quasiexperimental design.

When the data collection tools used in the studies within the scope of the research are analyzed, findings of this research reveal that the most preferred data collection tools at both national and international levels are questionnaires/scales. According to Kurt and Erdoğan (2015), the reasons for the widespread usage of questionnaires and scales as data collection tool in research can be that they provide the opportunity to reach a larger number of participants and to enable the data collection process to be carried out in a shorter time and more economically. In other words, it can be said that questionnaires and scales facilitate researchers in the data collection process. Therefore, the reason why questionnaires and scales are preferred more in the studies can be attributed to the convenience they provide. Nawaila et al. (2020) also confirms this view in his content analysis. In the study conducted by Nawaila et al. (2020), it was determined that surveys were the most preferred data collection tool due to the convenience they provide to researchers. A similar finding was obtained in the content analysis study conducted by Yağız, Aydın, and Akdemir (2016). Yağı et al. (2016) examined the studies on teaching English as a foreign language in Turkey, and it was found that questionnaire /scale data collection tools were used more widely in these studies. In addition, in present content analysis study, it was determined that the most used data collection tools after questionnaires/scales were interviews and achievement tests. These findings are in line with many studies in the literature and it has been found that these data collection tools are more preferred. Başaran (2017) examined 79 postgraduate thesis studies conducted in Turkey between $2010-2016$ to determine the role of 
technology integration in foreign language teaching. In the study carried out by Başaran (2017), it was stated that the most used data collection tools were questionnaires, interviews, and achievement tests. Moreover, in a similar study conducted by Akbaba and Tunagür (2018), 142 studies about the use of information technologies in language skills carried out in Turkey were examined. Akbaba and Tunagür (2018) stated that the most preferred data collection tools were questionnaires, interviews, and achievement tests.

When the data analysis techniques which were used in the studies within the scope of the research were analyzed, it was determined that the most used data analysis technique at both national and international level was descriptive statistics. Considering that almost every study needs values such as frequency, percentage, mean, standard deviation, the descriptive statistics are expected situation to be the most commonly used data analysis technique. Descriptive statistics is a data analysis technique used by researchers in all qualitative or quantitative research. A similar finding was obtained in the content analysis study conducted by Filiz and Benzet (2018). In their study, Filiz and Benzet (2018) examined 50 studies published between 2014 and 2018 to state the role of flipped learning in foreign language teaching and they concluded that both mean and standard deviation values were used frequently in these studies. In addition, in present content analysis study, it was determined that the most used data analysis technique after descriptive statistics is the $t$ test. A similar finding was obtained in the content analysis study led by Akbaba and Tunagür (2018), and it was found that the most commonly used data analysis technique in research was the $t$ test. When the data analysis techniques used in the studies examined within the scope of the present research are evaluated in general, it can be said that inferential analysis techniques such as regression and Manova, which are more complex than the $t$ test, are not preferred much. A similar finding was attained in the content analysis study conducted by Yağız et al. (2016) and it was concluded that although the $t$ test was used quite often, techniques such as Manova and regression were slightly used.

As for the sample groups of the studies within the scope of the research, it is found that university students are the most studied group at both national and international levels. One of the possible reasons for this situation can be shown as that it is easier to reach university students as a sample group. Also, similar findings were obtained in many studies conducted in the literature. In this line, 78 studies, which were about the role of flipped learning in teaching English as a foreign language, were examined in the content analysis study conducted by Arslan (2020). In the study conducted by Arslan (2020), it was found that most of the sample groups consisted of university students. 40 studies, conducted by Solak and Erdem (2015) for the content analysis study, which were about the role of virtual reality in foreign language teaching carried out between the years 1995 and 2015, were examined. As a result of the study led by Solak and Erdem (2015), it was found that the most preferred group as a sample is undergraduate students' group. Furthermore, in the content analysis studies conducted by Akbaba and Tunagür (2018), Filiz and Benzet (2018) and Yağız et al. (2016), it was stated that university students are mostly preferred group as the sample group. When the sample groups of the studies examined within the scope of the present research are evaluated in general, it can be said that there are fewer studies for students in the younger age group. However, an effective foreign language education should start from an early age (Arslan \& Akbarov, 2010; Özer \& Korkmaz, 2016). In this respect, it can be stated that there are very small number of studies on the role of technology integration in foreign language teaching, especially in pre-school and primary school period, which is a significant deficiency in the literature.

When the sample sizes of the studies within the scope of the research are analyzed, it is found that the most studied sample size is in the range of 0-50. This result is same not only at the national but international level also. One of the possible reasons for this situation could result from the fact that more experimental studies are preferred in the literature since experimental studies work with small sample groups. This tendency is consistent with other content analysis studies conducted by Filiz and Benzet (2018) and Akbaba and Tunagür (2018), and it was found that the sample size was generally in the range of 0-50 in the studies. It can be stated that there are fewer studies for large sample groups in point of sample sizes of the studies. 
A similar finding was obtained in content analysis study by Yağız et al. (2016) and it was stated that few studies were conducted with a sample size of 300 or more.

When the results of the studies within the scope of the research are analyzed, the most observed result at both national and international level is that the views of participants on technology integration are favorable. In other words, it can be expressed that the participants have a positive attitude towards the use of technology integration in teaching English as a foreign language. Similar findings were obtained in many studies conducted in the literature. In the content analysis study conducted by Zengin and Aksu (2017), 47 studies conducted in Turkey between 2005-2016 regarding the role of technology integration in foreign language teaching were examined. As a result of their study, Zengin and Aksu (2017) have stated that both learners and teachers have positive attitudes towards technology integration in foreign language teaching. Moreover, it was found that the learners' attitudes towards using mobile technologies in foreign language teaching were positive in the content analysis study conducted by Viberg and Grönlund (2012). In addition, another result highlighted in the studies examined within the scope of the research is that technology integration increases the motivation for learning English as a foreign language. This result is considered invaluable as it is very difficult to motivate individuals whose native language is different so as to acquire English. Thanks to technology integration, learning English becomes more interesting, which affects the motivation of learners positively (Hazarika, 2017). Similar findings were obtained in many studies conducted in the literature. Panagiotidis, Krystalli, and Arvanitis (2018) focused on technology as a motivating factor in foreign language teaching and examined the studies on this subject. Panagiotidis et al. (2018) concluded that technology integration affected the motivation of foreign language learners positively, so learners participate to the teaching-learning process willingly. On the other hand, Kartal (2020), based on three journals that included publications on computer-assisted language teaching in his content analysis study and he examined the studies that benefited from technology integration in language teaching in these journals. As a result of the studies he examined, Kartal (2020) stated that one of the areas most benefited from technology was motivation and technology integration, which influences the participants' motivation positively. When the obtained results from the studies examined within the scope of the present research are evaluated in general, it can be said that technology integration has a positive effect on teaching English as a foreign language.

As for the suggestions of the studies, suggestions for the sampling are given both at the national and international level. When the studies are reviewed, it has been suggested to conduct studies in different and larger sample groups. When it is considered that the sample group consisting of university students mostly and most of the studies were studied in small sample groups, it is not surprising to make such recommendations. . When the studies are examined, one of the remarkable suggestions is to encourage participants in technology integration by organizing in-service training and seminars. This recommendation is also quite important as teachers can be thought of as digital immigrants in technology in most of the cases today. In other words, teachers teaching students who are digital natives can sometimes fall behind their students on technology. This situation could cause teachers to have a negative attitude towards technology integration (Abunowara, 2014). In this kind of situation, their views may be changed in a positive way via in-service training or seminars, which could encourage them to integrate technology into the teachinglearning process. In addition, one of the remarkable suggestions from the studies examined is that technology integration should be included in curricula and textbooks. This suggestion could also be considered very valuable in order to put into practice. According to Larsen-Freeman and Anderson (2011), technology, which has the power to change the nature of learning in foreign language teaching, should also be integrated into curricula. Teaching-learning process is always based on curricula and textbooks. If technology integration is desired to be used in teaching English as a foreign language, this situation should be emphasized in the curriculum and textbooks, also the activities should be arranged in this direction. 


\section{Conclusion}

As a result of this study, it can be said that there is a similarity of the trends of both national and international studies. The findings have shown that there is an increasing trend in the number of studies conducted on this subject. This increase could be inferred that technology has been used in teaching English as a foreign language more. Especially, flipped classroom and mobile assisted language learning have been getting more interesting. When the methodological tendencies of the studies within the scope of the research are analyzed, it is seen that experimental studies were conducted more to investigate the effectiveness of technology integration. While questionnaires/scales providing convenience to the researchers are preferred more, data analysis techniques such as descriptive statistics and t-test are frequently used. Another finding is about the sample groups and sizes. Researchers mostly studied with students at higher education and small sample groups. This could be attributed to the sample accessibility of the researchers. Regarding the results of the studies, the most emphasized results are the participants' views on technology integration are positive and technology integration increases the motivation for learning English as a foreign language. Based on these results, it can be stated that technology integration has positive effects on teaching English as a foreign language. It can also be accepted as an indication that technology integration will continue in teaching English as a foreign language. As for the suggestions of the studies within the scope of the research, it has been suggested to conduct studies in different and larger sample groups. In other words, the most emphasized suggestions of the studies are related to further research in this area. It could be inferred that there is a need for further research related to the role of technology integration in foreign language teaching. Accordingly, it is thought that this study could be a guide for future studies.

\section{Limitations}

The current study aims to identify research trends which have been conducted over the last five years on the role of technology integration in teaching English as a foreign language. This study is limited to studies conducted between 2016 -2020. In line with this, two national (Council of Higher Education National Thesis Center and TR Index) and one international (Web of Science) database were selected. Hence, this study is limited to studies obtained from these three databases.

\section{Recommendations}

In the research, the trends of studies conducted in the last five years on the role of technology integration in teaching English as a foreign language were established. Considering the trends of the studies examined within the scope of the research, the following recommendations can be given:

- Studies can be conducted to examine the role of technologies such as robotic coding and Web 3 tools, which have been popular in recent years, in teaching English as a foreign language.

- It could be conducted further researches in which qualitative research designs such as phenomenology and embedded design are preferred. In this way, more in-depth information can be obtained about the role of technology integration.

- Further research can be conducted using student portfolios and lesson plans as data collection tools. Thus, both data diversity can be provided and data reflecting the development in the process can be obtained.

- Further research can be conducted where models are developed using data analysis techniques such as Regression, Factor analysis. Thus, the relationships between the variables can be shown on the models.

- In order to gain different perspectives on the role of technology integration, partners who are apart from teachers and learners can also be involved in research. Accordingly, further research can be conducted in which partners such as school administrators and parents form the sample group. 
- Considering that teaching English as a foreign language should start at an early age, it can be said that the integration of technology into foreign language teaching should start from pre-school and primary school periods. In this sense, further research can be conducted in which the sample group of students in the younger age group such as preschool and primary school students is formed.

- Further research can be conducted in large sample groups to generalize the results obtained from the studies.

\section{References}

Abunowara, A. M. (2014). Using technology in EFL/ESL classroom. International Journal of Humanities and Cultural Studies, 1(2), 1-18.

Aduwa-Ogiegbaen, S. E. O. (2009). Nigerian inservice teachers' self-assessment in core technology competences and their professional development needs in ICT. Journal of Computing in Teacher Education, 26(1), 17-28.

Ahmadi, M. R. (2018). The use of technology in English language learning: A literature review. International Journal of Research in English Education, 3(2), 115-125. doi: 10.29252/ijree.3.2.115

Akbaba, R. S., \& Tunagür, M. (2018). A content analysis on the use of information technologies in the language skills. Journal of A ̆grı İbrahim Çeçen University Social Sciences Institute, 4(2), 127-146. doi: 10.31463/aicusbed.427196

Akçayır, M., \& Akçayır, G. (2016). University Students' Opinions about Use of Augmented Reality in Foreign Language Teaching. Erzincan University Journal of Education Faculty, 18(2), 1169-1186. doi: $10.17556 /$ jef.86406

Alhujaylan, H. (2019). An assessment of the effectiveness of CALL in teaching English language writing skills in Saudi Arabia. Arab World English Journal (5), 18-27. doi: 10.24093/awej/call5.2

Almogheerah, A. (2020). Exploring the effect of using whatsapp on Saudi female EFL students' idiomlearning. Arab World English Journal, 11(4), 328-350. doi: 10.24093/awej/voll1 no4.22

Al-Wasy, B. Q. (2020). The effectiveness of integrating technology in EFL/ESL writing: a meta-analysis. Interactive Technology and Smart Education, 17(4), 435-454. doi: 10.1108/ITSE-03-2020-0033

Arslan, A. (2020). A systematic review on flipped learning in teaching English as a foreign or second language. Journal of Language and Linguistic Studies, 16(2), 775-797. doi: 10.17263/j1ls. 759300

Arslan, M., \& Akbarov, A. (2010). The matter of motivation-method and solution offers in foreign language teaching in Turkey. Selcuk University Journal of Faculty of Letters, (24), 179-191.

Aslan, E. (2017). Educational evaluation of design processes of computer programs used in foreign language teaching. Sinop University Journal of Social Sciences, 1(2), 149-178.

Aydin, S. (2018). Technology and foreign language anxiety: implications for practice and future research. Journal of Language and Linguistic Studies, 14(2), 193-211.

Başaran, B. (2017). Review of the postgraduate thesis prepared for the use of technology in foreign language teaching. Turkish Studies, 12(23), 15-40. doi: 10.7827/TurkishStudies.12126

Bensalem, E. (2018). The impact of WhatsApp on EFL students' vocabulary learning. Arab World English Journal, 9(1), 23-38. doi: 10.24093/awej/vol9no1.2

Bowen, G. A. (2009). Document analysis as a qualitative research method. Qualitative Research Journal, 9(2), 27-40. doi: 10.3316/QRJ0902027 
Chapelle, C. A. (2003). English language learning and technology: Lectures on applied linguistics in the age of information and communication technology. Amsterdam: John Benjamins Publishing.

Chang, M. M., \& Hung, H. T. (2019). Effects of technology-enhanced language learning on second language acquisition: A meta-analysis. Educational Technology \& Society, 22(4), 1-17.

Cok, T. (2016). ICT-supported language learning tools for Chinese as a foreign language: a content review. Revija za Elementarno Izobraževanje, 9(3), 103-120.

Çalık, M., \& Sözbilir, M. (2014). Parameters of content analysis. Education and Science, 39(174), 33-38. doi: 10.15390/EB.2014.3412

Demir, Y., \& Yavuz, M. (2014). A comparative analysis of the English language curricula in Finland, Japan, Korea, China (Shanghai) and Turkey. Mediterranean Journal of Humanities, 4(1), 115-128. doi: 10.13114/MJH.201416428

Enayati, F., \& Gilakjani, A. P. (2020). The impact of computer assisted language learning (CALL) on improving intermediate EFL learners' vocabulary learning. International Journal of Language Education, 4(1), 96-112. doi: 10.26858/ijole.v4i2.10560

Filiz, S., \& Benzet, A. (2018). A content analysis of the studies on the use of flipped classrooms in foreign language education. World Journal of Education, 8(4), 72-86. doi: 10.5430/wje.v8n4p72

Haidari, S. M., Baysal, S. \& Kanadl1, S. (2020). The impact of digital technology-mediated foreign language instruction on vocabulary learning: a meta-analytic review. Bolu Abant Izzet Baysal University Journal of Faculty of Education, 20(1), 236-251. doi: 10.17240/aibuefd.2020.20.52925552769

Hazarika, Z. (2017). Exploring the impact of technology in teaching English: Tesol in the context. European Journal of English Language and Literature Studies, 5(10), 19-28.

Ho, S. C., Hsieh, S. W., Sun, P. C., \& Chen, C. M. (2017). To activate English learning: Listen and speak in real life context with an AR featured u-learning system. Educational Technology \& Society, 20(2), 176-187.

Karabulut, H. İ. (2020). The effectiveness of technology-enhanced language teaching methods on achievement in english: a meta-analysis. (Unpublished doctoral thesis). University of Eskişehir Osmangazi, Eskişehir.

Kartal, G. (2020). An analysis of using technology in language learning in three flagship journals. Mehmet Akif Ersoy University Journal of Education Faculty, (53), 515-532. doi: 10.21764/maeuefd.645551

Kaymak, B. (2019). The effect of multimedia based warm-up activities on students' motivation and participation in english lesson. (Unpublished master's thesis). University of Ankara, Ankara.

Kırmızı, Ö., \& Kömeç, F. (2019). The impact of the flipped classroom on receptive and productive vocabulary learning. Journal of Language and Linguistic Studies, 15(2), 437-449.

Kizmaz, Z. (2019). The use of call to foster learner autonomy in EFL: a quasi-experimental study. (Unpublished master's thesis). Middle East Technical University, Ankara.

Köprülü, F., Öznacar, B., \& İlginç Demirsu, Ö. (2020). A meta-analysis of educating second language learners through technology. Applied Linguistics Research Journal, 4(7), 101-107. doi: 10.14744/alrj.2020.66934

Kurt, A., \& Erdoğan, M. (2015). Content analysis and trends of curriculum evaluation research: 2004- 2013. Education and Science, 40(178), 199-224. doi: 10.15390/EB.2015.4167 
Larsen-Freeman, D., \& Anderson, M. (2011). Techniques \& principles in language teaching. New York: Oxford University Press.

Mei, J., Guo, Y., \& Li, X. (2017). Adaptive learning mode of a multimedia-based" English literature" learning system. International Journal of Emerging Technologies in Learning, 12(1), 71-83. doi: 10.3991/ijet.v12i01.6483

Merriam, S. B. (2009). Qualitative research: A guide to design and implementation. San Francisco, CA: Jossey-Bass.

Miles, M. B., \& Huberman, A. M. (1994). An expanded sourcebook qualitative data analysis. London: Sage Publications.

Nawaila, M. B., Kanbul, S., \& Alhamroni, R. (2020). Technology and English language teaching and learning: a content analysis. Journal of Learning and Teaching in Digital Age, 5(1), 16-23.

Okojie, M. C. P. O., Olinzock, A. A., \& Okojie-Boulder, T. C. (2006). The pedagogy of technology integration. The Journal of Technology Studies, 32(2), 66-71. doi: 10.21061/jots.v32i2.a.1

Özer, B., \& Korkmaz, C. (2016). Factors affecting student achievement in foreign language teaching abstract. Ekev Academy Journal, 20(67), 59-84.

Panagiotidis, P., Krystalli, P., \& Arvanitis, P. (2018). Technology as a motivational factor in foreign language learning. European Journal of Education, 1(3), 43-52.

Persson, V., \& Nouri, J. (2018). A systematic review of second language learning with mobile technologies. International Journal of Emerging Technologies in Learning, 13(2), 188-210. doi: 10.3991/ijet.v13i02.8094

Pokrivcakova, S. (2019). Preparing teachers for the application of AI-powered technologies in foreign language education. Journal of Language and Cultural Education, 7(3), 135-153. doi: 10.2478/jolace-2019-0025

Polat Demir, B., \& Kutlu, Ö. (2016). The effect of electronic portfolio applications on 6th graders' research skills. Education and Science, 41(188), 227-253. doi: 10.15390/EB.2016.6724

Prensky, M. (2001). Digital natives, digital immigrants part 1. On the Horizon, 9(5), 1-6.

Shyamlee, S. D., \& Phil, M. (2012). Use of technology in English language teaching and learning: An analysis. International Proceedings of Economics Development and Research, (33), 150-156.

Solak, E., \& Erdem, G. (2015). A content analysis of virtual reality studies in foreign language education. Participatory Educational Research, 2, 21-26. doi: 10.17275/per.15.spi.2.3

Suna, Y., \& Durmuşçelebi, M. (2013). A compilation work about why turkey suffers from learning and teaching english. OPUS International Journal of Society Researches, 3(5), 31-48.

Suranakkharin, T. (2017). Using the flipped model to foster Thai learners' second language collocation knowledge. 3L: The Southeast Asian Journal of English Language Studies, 23(3), 1-20. doi: 10.17576/3L-2017-2303-01

Şahan, Ö., Çoban, M., \& Razı, S. (2016). Students learn English idioms through WhatsApp: Extensive use of smartphones. Erzincan University Journal of Education Faculty, 18(2), 1230-1251. doi: 10.17556/jef.72045

Taj, I. H., Sulan, N. B., Sipra, M. A., \& Ahmad, W. (2016). Impact of mobile assisted language learning (MALL) on EFL: A meta-analysis. Advances in language and literary studies, 7(2), 76-83. doi: 10.7575/aiac.alls.v.7n.2p.76 
Teng, M. F. (2017). Flipping the classroom and tertiary level EFL students' academic performance and satisfaction. The Journal of Asia TEFL, 14(4), 605-620. doi: 10.18823/asiatefl.2017.14.4.2.605

Tsai, C. C. (2020). The effects of augmented reality to motivation and performance in EFL vocabulary learning. International Journal of Instruction, 13(4), 987-1000. doi: 10.29333/iji.2020.13460a

Türkben, T. (2018). Evaluation of postgraduate studies conducted on teaching Turkish as a foreign language. International Journal of Turkish Literature Culture Education, 7(4), 2464-2479.

Türker, M. S., \& Genç, A. (2018). Students' and Teachers' Views on Instructional Use of Blogs in Teaching Turkish as a Foreign Language. Selçuk University Journal of Faculty of Letters, (39), 251-266.

Uzunboylu, H., \& Genç, Z. (2017). Analysis of documents published in Scopus database on foreign language learning through mobile learning: A content analysis. Profile Issues in Teachers' Professional Development, 19(Suppl. 1), 99-107. doi: 10.15446/profile.v19n_sup1.68624

Valeev, A. A., Latypova, L. A., \& Latypov, N. R. (2016). The use of interactive learning technologies in teaching a foreign language in high school. International Electronic Journal of Mathematics Education, 11(6), 1773-1785.

Viberg, O., \& Grönlund, A. (2012). Mobile assisted language learning: A literature review. In proceedings of the 11th international conference on mobile and contextual learning (pp. 9-16). Helsinki.

Vitta, J. P., \& Al-Hoorie, A. H. (2020). The flipped classroom in second language learning: A metaanalysis. Language Teaching Research. doi: 10.1177/1362168820981403

Yağız, O., Aydın, B., \& Akdemir, A. S. (2016). ELT research in Turkey: A content analysis of selected features of published articles. Journal of Language and Linguistic Studies, 12(2), 117-134.

Zengin, Ö., \& Aksu, M. (2017). A review study on the integration of technology into foreign language education in Turkey. Ankara University, Journal of Faculty of Educational Sciences, 50(2), 79-104.

Zhao, Y. (2003). Recent developments in technology and language learning: A literature review and metaanalysis. CALICO Journal, 21(1), 7-27.

Zhao, X., Wang, Y., Liu, Y., Xu, Y., Meng, Y., \& Guo, L. (2019). Multimedia based teaching platform for English listening in universities. International Journal of Emerging Technologies in Learning, 14(4), 160-168. doi: 10.3991/ijet.v14.i04.9690 